\title{
Pengaruh Pemberian Pupuk Mikro Zn dan Cu serta Pupuk Tanah terhadap Perkembangan Empoasca sp. pada Areal Tanaman Teh
}

\author{
Fani Fauziah, Restu Wulansari dan Erdiansyah Rezamela \\ Pusat Penelitian Teh dan Kina \\ PO Box 1013. Bandung Gambung 40010 - Jawa Barat \\ *Alamat korespondensi: fani_fauziah@ymail.com
}

\begin{abstract}
The effect of $\mathrm{Zn}$ and $\mathrm{Cu}$ micro-fertilizer and soil fertilizer on the development of Empoasca sp. in tea plantation area
\end{abstract}

Fertilization has an important role for the entire process of metabolism and improves plant health. Tea plants are plants that require macro and micro nutrient inputs. The micro elements of $\mathrm{Zn}$ and $\mathrm{Cu}$ are needed for energy production, protein synthesis, formation of auxin hormones and increament of plant resistance to pest attack. This study aimed to determine the effect of $\mathrm{Zn}$ and $\mathrm{Cu}$ micro fertilizer and soil fertilizer on the development of Empoasca sp. The study was conducted from January to July 2017 at Gambung Experimental Station with an altitude of 1350 asl. The experiment was designed with Randomized Block Design (RBD) Factorial pattern with the following treatment arrangement: Factor $\mathrm{A}=1$ ) Without Micro Fertilizer, 2) Micro Fertilizer of Zn and $\mathrm{Cu} 200 \mathrm{~g} / \mathrm{ha}$ /application, and 3) $\mathrm{Zn}$ and $\mathrm{Cu} 300 \mathrm{~g} / \mathrm{ha}$ /application; Factor B = 1) Soil fertilizer of $100 \%$ recommended dosage, 2) Soil fertilizer of $75 \%$ recommended dosage, and 3) Soil fertilizer of $50 \%$ recommended dosage. All treatmnets were repeated three times. Application of micro fertilizers was carried out after six times of tea-leaf picking, while soil fertilizer was applied once at the beginning of the experiment. Observation parameters were population and attack intensity of Empoasca sp., as well as shoot production $\left(\mathrm{kg} / 25 \mathrm{~m}^{2}\right.$ plot size). The results showed that the application of fertilizers had an effect on the decrease of attack intensity and the population of Empoasca sp. in all treatments. Average attack intensity and population of Empoasca sp. at the end of the observation did not differ significantly of $31.64 \%$ and 2.55 Empoasca sp. per plant. Meanwhile, the highest total production of $36.56 \mathrm{~kg} / \mathrm{plot}$ was obtained from the application of micro fertilizer $\mathrm{Zn}$ and $\mathrm{Cu}$ in the dosage of $200 \mathrm{~g} / \mathrm{ha} /$ application at all doses of soil fertilizer, but there was no interaction between treatment factors.

Keywords: Micro fertilizer, Soil fertilizer, Empoasca sp., Tea plant

\begin{abstract}
ABSTRAK
Pemupukan memegang peranan penting untuk seluruh proses metabolisme dan meningkatkan kesehatan tanaman. Tanaman teh merupakan tanaman yang memerlukan input unsur hara makro dan mikro. Unsur mikro $\mathrm{Zn}$ dan $\mathrm{Cu}$ diperlukan tanaman untuk produksi energi, sintesis protein, pembentukan hormon auksin serta meningkatkan resistensi terhadap serangan organisme pangganggu tanaman. Penelitian ini bertujuan untuk mengetahui dampak pemberian pupuk mikro $\mathrm{Zn}$ dan $\mathrm{Cu}$ serta pupuk tanah terhadap perkembangan Empoasca sp. Penelitian dilaksanakan dari bulan Januari hingga Juli 2017 di Kebun Percobaan Gambung dengan ketinggian 1.350 mdpl. Percobaan dirancang dengan Rancangan Acak Kelompok (RAK) pola Faktorial dengan susunan perlakuan sebagai berikut: Faktor $\mathrm{A}=1$ ) Tanpa Pupuk mikro, 2) Pupuk mikro Zn dan Cu 200 g/ha/aplikasi, dan 3) Pupuk mikro Zn dan Cu 300 g/ha/aplikasi; Faktor B = 1) Pupuk tanah 100\% dosis anjuran, 2) Pupuk tanah 75\% dosis anjuran, dan 3) Pupuk tanah 50\% dosis anjuran. Perlakuan diulang sebanyak tiga kali ulangan. Aplikasi pupuk mikro dilaksanakan setelah pemetikan sebanyak enam kali, sedangkan pemberian pupuk tanah dilakukan satu kali diawal percobaan. Parameter pengamatan yaitu populasi, intensitas serangan Empoasca sp., dan produksi pucuk (kg/plot $25 \mathrm{~m}^{2}$ ). Hasil penelitian menunjukkan bahwa pemberian pupuk berpengaruh terhadap penurunan
\end{abstract}


intensitas serangan dan populasi Empoasca sp. pada seluruh perlakuan. Rata-rata intensitas serangan dan populasi Empoasca sp. pada akhir pengamatan tidak berbeda nyata sebesar 31,64\% dan 2,55 ekor per tanaman. Sementara itu, total produksi tertinggi diperoleh dari aplikasi pupuk mikro Zn dan $\mathrm{Cu}$ dosis $200 \mathrm{~g} / \mathrm{ha} /$ aplikasi pada semua dosis pupuk tanah yaitu sebesar 36,56 kg/plot, namun tidak terjadi interaksi antar faktor perlakuan.

Kata Kunci: Pupuk mikro, Pupuk tanah, Empoasca sp., Tanaman teh

\section{PENDAHULUAN}

Tanaman teh (Camellia sinensis) merupakan salah satu komoditas perkebunan yang memiliki arti penting dalam perekonomian Indonesia seperti menyediakan lapangan pekerjaan, sumber pendapatan petani, menambah devisa negara dan mendorong pengembangan wilayah (Direktorat Jenderal Bina Perkebunan, 2002). Namun, dalam praktek budidaya tanaman teh terdapat pula permasalahan yang dapat menurunkan produksi pucuk seperti penerapan teknologi budidaya yang masih rendah dan adanya organisme pengganggu tanaman (OPT) (Fauziah, 2013).

Salah satu OPT utama pada tanaman teh adalah Empoasca sp. yang menyerang bagian pucuk tanaman teh. Empoasca sp. merupakan polyfag yang memiliki banyak tanaman inang alternatif (Kalshoven, 1981). Empoasca sp. dewasa dan nimfa menyerang dengan cara menghisap cairan daun menggunakan stilet. Pada serangan yang berat selama 45 hari berturut-turut dapat menurunkan produksi pucuk teh hingga 50\% (Dharmadi, 1999).

Sebagian besar pengendalian Empoasca sp. di perkebunan masih menggunakan insektisida kimia. Namun, penggunaan insektisida yang berlebihan tidak sesuai dengan rekomendasi dapat menimbulkan berbagai efek negatif seperti resistensi, resurgensi, terbunuhnya musuh alami dan residu pada pucuk teh (Sucherman \& Sukandi, 2008). Seiring dengan meningkatnya kesadaran konsumen terhadap kesehatan, produk bebas residu pestisida dan kesadaran terhadap lingkungan, mendorong proses pengendalian yang lebih ramah lingkungan dan aman terhadap kesehatan (PPTK, 2006). Oleh karena itu, diperlukan pengendalian yang lebih bijaksana untuk meminimalkan penggunaan pestisida dengan meningkatkan kesehatan tanaman melalui pemupukan.

Pemupukan merupakan salah satu upaya untuk meningkatkan kesehatan tanaman, dengan tujuan untuk memenuhi kebutuhan unsur hara bagi tanaman teh agar tanaman teh berada dalam kondisi yang sehat (PPTK, 2006). Tanaman teh memerlukan hara yang tersedia secara teratur dan berkecukupan berupa unsur hara makro dan mikro. Unsur hara mikro yang dibutuhkan oleh tanaman teh adalah unsur seng (Zn), Zn merupakan unsur mikro esensial yang berperan sebagai ko-faktor lebih dari 300 jenis enzim yang berperan dalam metabolisme asam nukleat, pembelahan sel dan sintesis protein. Selain itu, dapat meningkatkan kesehatan dan produktivitas tanaman serta meningkatkan resistensi terhadap serangan OPT (Sarwar, 2011; Gogi et al., 2012). Sementara itu, unsur $\mathrm{Cu}$ merupakan salah satu unsur mikro esensial unuk pertumbuhan tanaman, pembentukan klorofil dan ketahanan tanaman terhadap penyakit.

Pemberian unsur hara makro diberikan melalui pemupukan tanah, dengan jenis pupuk tunggal seperti Urea, SP 36, MOP, Kiserit yang diberikan secara berimbang atau pupuk yang sudah dicampur baik pupuk majemuk atau pupuk campuran. Pupuk yang digunakan dalam penelitian ini merupakan pupuk mikro yang mengandung unsur $\mathrm{Zn} \mathrm{30 \%} \mathrm{dan} \mathrm{Cu}$ 30\% yang diaplikasikan melalui daun serta pupuk $\mathrm{N}, \mathrm{P}$ dan $\mathrm{K}$ yang diaplikasikan melalui tanah. Penelitian ini bertujun untuk mengetahui pengaruh pemberian pupuk daun mikro Zn dan $\mathrm{Cu}$ terhadap perkembangan Empoasca sp. dan pertumbuhan tanaman teh serta produksi pucuk teh.

\section{BAHAN DAN METODE}

Percobaan dilakukan selama \pm 7 bulan, dari Bulan Januari hingga Juli 2017, di Kebun Percobaan Gambung, Kabupaten Bandung, Jawa Barat dengan ketinggian tempat $1.350 \mathrm{~m}$ di atas permukaan laut. Bahan tanam menggunakan klon GMB 7 Tahun Pangkas ke-2 (TP-2). Penelitian menggunakan Rancangan Acak Kelompok (RAK) pola faktorial dengan 2 (dua) taraf perlakuan dan ulangan 3 kali. Jumlah plot penelitian adalah 27 plot dengan luas 1 patok $\left(5 \times 5 \mathrm{~m}^{2}\right)$ per plot. Adapun perlakuannya adalah sebagai berikut:

A. Faktor pertama adalah dosis pupuk mikro dengan 3 level:

1) Tanpa Pupuk Mikro (A1)

2) Pupuk Mikro 200 g/ha/aplikasi (A2) 
3) Pupuk Mikro $300 \mathrm{~g} / \mathrm{ha} /$ aplikasi (A3)

B. Faktor kedua adalah dosis pupuk dasar kebun (tanah):

1) $100 \%$ dosis anjuran (B1)

2) $75 \%$ dosis anjuran (B2)

3) $50 \%$ dosis anjuran (B3)

Aplikasi pupuk tanah dilakukan sebanyak satu kali pada awal percobaan dengan dosis 100\%: Urea 444 g/ha, TSP 130 g/ha, dan KCl 170 g/ha. Perlakuan pupuk mikro diaplikasikan satu hari setelah pemetikan sebanyak 6 kali dengan interval aplikasi 28 hari.

Parameter pengamatan terdiri dari intensitas dan populasi Empoasca p., analisa pucuk, dan produksi pucuk basah. Pengamatan parameter intensitas, analisa pucuk dan produksi pucuk basah dilakukan saat pemetikan pucuk, sedangkan pengamatan populasi dilaksanakan satu hari sebelum pemetikan.

Pengamatan populasi Empoasca sp. dilaksanakan dengan menggunakan metode "beat bucket" (Sucherman \& Widayat, 2001; Widayat, 2008). Untuk menghitung populasi digunakan rumus:

Keterangan:

$$
\mathrm{P}=\frac{\mathrm{a}}{\mathrm{b}}
$$

$\mathrm{P}=$ Populasi Empoasca sp./perdu

$\mathrm{a}=$ Jumlah Empoasca sp. (semua stadia)

$\mathrm{b}=$ Jumlah perdu yang diamati

Intensitas serangan Empoasca sp. ditentukan dengan cara menghitung jumlah pucuk p+3 yang sehat dan yang terinfeksi dari 100 pucuk sampel yang diambil secara acak dari masing-masing petak. Intensitas serangan Empoasca sp. dihitung dengan rumus berikut:

$$
I=\left(\frac{a}{a+b}\right) \times 100
$$

Keterangan : $\mathrm{I}=$ intensitas hama $(\%)$

$$
\mathrm{a}=\text { Jumlah pucuk } \mathrm{p}+3 \text { yang terserang }
$$$$
\mathrm{b}=\text { Jumlah pucuk } \mathrm{p}+3 \text { yang sehat }
$$

Pengamatan Produksi pucuk (kg/plot) diamati dengan menimbang bobot pucuk segar pada masing-masing plot perlakuan. Analisa petikan per plot dilakukan dengan cara mengambil pucuk sebanyak $100 \mathrm{~g}$ secara acak dari hasil produksi pada setiap plot. Kemudian pucuk dipisahkan antara pucuk peko dan pucuk burung dan dihitung antara jumlah pucuk peko dan pucuk burung. Pucuk peko dan pucuk burung masing-masing ditimbang bobotnya. Rasio presentase peko terhadap burung (\%) dihitung dengan rumus:

$$
\text { Rasio peko }- \text { burung }=\frac{\text { Jumlah pucuk peko }}{\text { Jumlah pucuk burung }}
$$

Sementara itu, persentase pucuk peko dihitung dengan rumus:

$$
p=\frac{a}{a+b} \times 100 \%
$$

Keterangan:

$\mathrm{p}=$ Persentase pucuk peko

$\mathrm{a}=$ jumlah pucuk peko

$\mathrm{b}=$ jumlah pucuk burung

\section{HASIL DAN PEMBAHASAN}

Pengaruh Pemupukan terhadap Intensitas Serangan dan Populasi Empoasca sp. pada Tanaman Teh

Aplikasi pemupukan dapat dilakukan dengan dua cara yaitu melalui pemupukan tanah untuk unsur hara makro, dan untuk unsur hara mikro diberikan melalui pemupukan daun. Pemberian unsur hara mikro melalui daun dinilai lebih efektif dikarenakan unsur hara mikro yang diberikan akan lebih mudah diserap oleh tanaman melalui stomata yang terdapat pada daun. Pemupukan berperan dalam proses metabolisme, pembentukan struktur sel, dinding sel, dan meningkatkan kesehatan tanaman yang berperan secara langsung terhadap ketahanan tanaman terhadap serangan hama dan penyakit tanaman (Fragoyiannis et al., 2001; Gogi et al., 2012; Rouhani \& Samih, 2013).

Hasil penelitian menunjukkan bahwa terdapat penurunan intensitas serangan Empoasca sp. pada seluruh perlakuan setelah pengamatan kedua. Rata-rata intensitas serangan pada awal pengamatan adalah 50,13\%. Intensitas serangan Empoasca sp. sebesar $40-50 \%$ tergolong tingkat serangan out break (Widayat, 2000). Penurunan intensitas serangan Empoasca sp. terus terjadi hingga pengamatan terakhir (pengamatan ketujuh). Namun, berdasarkan hasil analisis statistik tidak terdapat perbedaan yang nyata antar perlakuan pada tiap pengamatan (Tabel 1).

Selain itu, tidak terdapat interaksi antara faktor pupuk daun dan pupuk tanah dalam menekan intensitas serangan Empoasca sp. Demikian pula dengan hasil pengamatan pada populasi Empoasca sp. Meskipun terjadi penurunan rata-rata populasi hingga pengamatan terakhir (pengamatan ketujuh) namun, tidak terdapat perbedaan yang nyata antar perlakuan berdasarkan hasil analisis statistik (Tabel 2). Rata-rata populasi Empoasca sp. pada awal pengamatan adalah 5,4 ekor/tanaman. Selain itu, tidak terdapat interaksi antara faktor pupuk daun dan pupuk tanah dalam menekan populasi serangan Empoasca sp. 
Penurunan intensitas serangan dan populasi Empoasca sp. terjadi secara fluktuatif. Populasi Empoasca sp. pada pengamatan keempat (Tabel 2.) meningkat dengan rata-rata populasi tertinggi sebesar 6,11 ekor/tanaman. Hal ini menyebabkan peningkatan intensitas serangan pada pengamatan kelima dengan rata-rata intensitas serangan tertinggi mencapai $40 \%$ pada perlakuan tanpa pupuk daun dan pupuk tanah dengan dosis 50\% (Tabel 1).

Tabel 1. Rata- rata Intensitas Empoasca sp. pada tiap pengamatan (\%).

\begin{tabular}{lccccccc}
\hline \multicolumn{1}{c}{ Perlakuan } & P1 & P2 & P3 & P4 & P5 & P6 & P7 \\
\hline Tanpa Pupuk mikro & $52,24 \mathrm{a}$ & $55,76 \mathrm{a}$ & $30,36 \mathrm{a}$ & $28,04 \mathrm{a}$ & $40,65 \mathrm{~b}$ & $38,02 \mathrm{a}$ & $30,20 \mathrm{a}$ \\
Pupuk mikro 200 g/ha & $49,86 \mathrm{a}$ & $56,64 \mathrm{a}$ & $33,07 \mathrm{a}$ & $30,29 \mathrm{ab}$ & $36,20 \mathrm{ab}$ & $34,70 \mathrm{a}$ & $32,08 \mathrm{a}$ \\
Pupuk mikro 300 g/ha & $48,28 \mathrm{a}$ & $58,28 \mathrm{a}$ & $30,19 \mathrm{a}$ & $32,11 \mathrm{~b}$ & $39,99 \mathrm{ab}$ & $35,67 \mathrm{a}$ & $32,64 \mathrm{a}$ \\
\hline Pupuk tanah 50\% & $52,49 \mathrm{a}$ & $57,68 \mathrm{a}$ & $30,58 \mathrm{a}$ & $30,66 \mathrm{a}$ & $40,87 \mathrm{~b}$ & $34,57 \mathrm{a}$ & $29,91 \mathrm{a}$ \\
Pupuk tanah 75\% & $48,53 \mathrm{a}$ & $56,97 \mathrm{a}$ & $31,19 \mathrm{a}$ & $29,96 \mathrm{a}$ & $36,35 \mathrm{a}$ & $35,82 \mathrm{a}$ & $32,39 \mathrm{a}$ \\
Pupuk tanah 100\% & $49,35 \mathrm{a}$ & $56,03 \mathrm{a}$ & $31,85 \mathrm{a}$ & $29,82 \mathrm{a}$ & $39,63 \mathrm{ab}$ & $38,01 \mathrm{a}$ & $32,60 \mathrm{a}$ \\
\hline
\end{tabular}

Keterangan: Angka yang diikuti huruf yang sama pada kolom yang sama menunjukkan tidak beda nyata berdasarkan uji lanjut Duncan (DMRT) dengan taraf kepercayaan 0,05.

Tabel 2. Rata- rata Populasi Empoasca sp. pada tiap pengamatan (ekor/tanaman).

\begin{tabular}{lccccccc}
\hline \multicolumn{1}{c}{ Perlakuan } & P1 & P2 & P3 & P4 & P5 & P6 & P7 \\
\hline Tanpa Pupuk mikro & $5,66 \mathrm{a}$ & $6,24 \mathrm{a}$ & $1,97 \mathrm{a}$ & $3,80 \mathrm{a}$ & $4,13 \mathrm{a}$ & $2,86 \mathrm{a}$ & $2,62 \mathrm{a}$ \\
Pupuk mikro 200 g/ha & $5,35 \mathrm{a}$ & $5,62 \mathrm{a}$ & $2,13 \mathrm{a}$ & $5,15 \mathrm{ab}$ & $3,42 \mathrm{a}$ & $3,08 \mathrm{a}$ & $2,42 \mathrm{a}$ \\
Pupuk mikro 300 g/ha & $5,20 \mathrm{a}$ & $5,31 \mathrm{a}$ & $1,68 \mathrm{a}$ & $6,11 \mathrm{~b}$ & $3,02 \mathrm{a}$ & $3,37 \mathrm{a}$ & $2,60 \mathrm{a}$ \\
\hline Pupuk tanah 50\% & $5,33 \mathrm{a}$ & $5,95 \mathrm{a}$ & $1,75 \mathrm{a}$ & $4,35 \mathrm{a}$ & $3,40 \mathrm{a}$ & $3,95 \mathrm{a}$ & $2,28 \mathrm{a}$ \\
Pupuk tanah 75\% & $5,66 \mathrm{a}$ & $5,75 \mathrm{a}$ & $2,08 \mathrm{a}$ & $5,93 \mathrm{a}$ & $3,53 \mathrm{a}$ & $2,75 \mathrm{~b}$ & $2,55 \mathrm{a}$ \\
Pupuk tanah 100\% & $5,22 \mathrm{a}$ & $5,46 \mathrm{a}$ & $1,95 \mathrm{a}$ & $4,77 \mathrm{a}$ & $3,64 \mathrm{a}$ & $2,62 \mathrm{ab}$ & $2,80 \mathrm{a}$ \\
\hline
\end{tabular}

Keterangan: Angka yang diikuti huruf yang sama pada kolom yang sama menunjukkan tidak beda nyata berdasarkan uji lanjut Duncan (DMRT) dengan taraf kepercayaan 0,05.

Rata-rata intensitas serangan Empoasca sp. pada pengamatan terakhir (pengamatan ketujuh) masih tinggi dengan rata-rata intensitas serangan lebih dari 30\% dengan rata-rata populasi lebih dari 2 ekor/tanaman. Intensitas serangan lebih dari $25 \%$ tergolong ke dalam serangan berat. Berdasarkan hasil penelitian Fauziah dkk. (2015), nilai koefisien korelasi kadar $\mathrm{Zn}$ pada daun bernilai positif yang berarti peningkatan intensitas serangan Empoasca sp. dapat diakibatkan oleh kadar $\mathrm{Zn}$ pada daun. Sementara itu, hubungan unsur $\mathrm{Zn}$ dengan populasi Empoasca sp. bernilai negatif yang berarti semakin tinggi kadar Zn pada daun maka semakin rendah populasi Empoasca sp. Oleh karena itu, tingkat serangan dan populasi Empoasca sp. dapat dipengaruhi oleh kandungan $\mathrm{Zn}$ pada daun.

Pengaruh Pemupukan terhadap Produksi Pucuk, Presentase Pucuk Peko, dan Rasio Peko/Burung Produksi Pucuk (kg/plot)

Berdasarkan hasil pengamatan selama $7 \mathrm{kali}$ pemetikan, produksi pucuk menunjukkan hasil signifikan terhadap perlakuan pupuk mikro Zn dan $\mathrm{Cu}$ (melalui daun) dengan pupuk tanah (melalui tanah) dibandingkan dengan tanpa di pupuk mikro, namun tidak terdapat interaksi antar kedua faktor perlakuan tersebut (Tabel 3). Total produksi tertinggi juga didapat dari aplikasi pupuk mikro dengan dosis $200 \mathrm{~g} / \mathrm{ha}$ pada semua pupuk tanah yaitu sebesar 36,56 kg per plot. Hal ini menunjukkan dengan pemberian pupuk mikro dan pupuk tanah dapat meningkatkan pertumbuhan hasil pucuk teh. Menurut Rachmiati dkk. (2013), pupuk yang diberikan melalui daun mudah diserap tanaman sehingga mampu merangsang pertumbuhan tunas.

Unsur hara mikro efektif diberikan melalui daun dan berfungsi sebagai pelengkap unsur hara (Hardjowigeno, 2007). Ketersediaan unsur hara sangat erat kaitannya dengan pertumbuhan tanaman, nutrisi dan konsentrasi bahan mineral yang ada di bumi (Nath, 2013). Selain itu, konsentrasi unsur hara daun tanaman teh berhubungan pula dengan kondisi tanah (Ozyazici et al., 2011).

Menurut Njogu et al. (2014), penyerapan nutrisi hara melalui daun dapat meningkatkan proses fotosintesis dan dapat degan cepat diubah menjadi unsur-unsur hara yang dibutuhkan tanaman, berbeda dengan pemupukan melalui tanah tidak dapat langsung diserap karena kehilangan melalui pelindian, penguapan, denitrifikasi. 
Berdasarkan hasil total produksi segar selama 7 pemetikan (Gambar 1), hasil produksi tertinggi pada perlakuan pupuk mikro $200 \mathrm{~g} / \mathrm{ha}$ dengan kombinasi pupuk tanah $100 \%$ dosis anjuran sebesar 37,32 kg/plot. Produksi kedua tertinggi pada perlakuan tanpa pupuk mikro dengan kombinasi pupuk tanah $75 \%$ sebesar $34,43 \mathrm{~kg} /$ plot dan diikuti oleh perlakuan pemberian pupuk mikro $300 \mathrm{~g} / \mathrm{ha}$ dengan pupuk tanah $50 \%$ sebesar $32,77 \mathrm{~kg} /$ plot. Hal ini menunjukkan bahwa kombinasi kedua pupuk tersebut mampu memberikan peningkatan produksi pucuk.

Pemupukan melalui tanah tidak dapat langsung diserap tanaman karena beberapa unsur hara ditransformasikan dahulu menjadi unsur hara yang dapat diserap tanaman. Menurut Rusmana \& Salim (2006) pemberian tanah dapat dikombinasikan dengan pupuk melalui daun, dengan pertimbangan bahwa batang dan daun dapat menghisap unsurunsur hara yang disemprotkan ke daun. Pemupukan melalui daun tidak dapat menggantikan fungsi akar yang digunakan untuk menyerap unsur hara dari dalam tanah, tetapi dalam hal-hal tertentu pemupukan lewat daun memberikan hasil yang efektif dan cepat terutama unsur-unsur mikro. Berdasarkan hasil penelitain Watanabe et al. (2015) pengaruh pemupukan pada tanah untuk bidang percobaan memberikan hasil dalam waktu jangka panjang.

Berdasarkan Sedaghathoor et al. (2009) bahwa unsur hara yang seimbang seperti $\mathrm{N}, \mathrm{K}, \mathrm{Mg}$ dan mikronutrien merupakan unsur-unsur hara penting untuk meningkatkan produktivitas dan kualitas teh. Pupuk tanah yang digunakan dalam penelitian ini mengandung $\mathrm{N}, \mathrm{P}$, dan $\mathrm{K}$. Peranan unsur $\mathrm{N}$ (Nitrogen) bagi tanaman adalah untuk merangsang pertumbuhan tanaman sera keseluruhan khusunya batang, cabang dan daun. Selain itu, ketersediaan hara di dalam tanah sangat dipengaruhi keadaan lengas sebagai pelarut pupuk dan unsur hara lainnya di dalam tanah (Rusmana \& Salim, 2006).

Tabel 3. Produksi pucuk (kg/plot) dan analisa pucuk.

\begin{tabular}{lccc}
\hline \multicolumn{1}{c}{ Perlakuan } & Produksi pucuk (kg/plot) & Persentase pucuk peko (\%) & Rasio peko/purung \\
\hline Tanpa Pupuk Mikro & $31,92 \mathrm{a}$ & $46,43 \mathrm{a}$ & $0,89 \mathrm{a}$ \\
Pupuk Mikro 200 gr/ha & $36,56 \mathrm{~b}$ & $49,00 \mathrm{a}$ & $0,96 \mathrm{a}$ \\
Pupuk Mikro 300 gr/ha & $30,90 \mathrm{a}$ & $49,04 \mathrm{a}$ & $0,97 \mathrm{a}$ \\
Pupuk tanah 50\% & $33,59 \mathrm{a}$ & $49,36 \mathrm{a}$ & $0,99 \mathrm{a}$ \\
Pupuk tanah 75\% & $32,74 \mathrm{a}$ & $45,76 \mathrm{a}$ & $0,86 \mathrm{a}$ \\
Pupuk tanah 100\% & $33,06 \mathrm{a}$ & $49,35 \mathrm{a}$ & $0,98 \mathrm{a}$ \\
\hline
\end{tabular}

Keterangan: Angka yang diikuti huruf yang sama pada kolom yang sama menunjukkan tidak beda nyata berdasarkan uji lanjut Duncan (DMRT) dengan taraf kepercayaan 0,05.

Menurut penelitian Sharma (2011), Seng (Zn) merupakan prekusor untuk hormon pertumbuhan auksin (IAA) yang berperan dalam pertumbuhan tunas aktif dan mampu meningkatkan hasil produksi teh. Seng tidak mudah diserap oleh tanaman teh dari tanah sehingga pemupukan melalui daun sangat efektif dalam memenuhi kebtuhan unsur-unsur mikro. Unsur Tembaga (Cu) merupakan unsur penting untuk tanaman teh. Menurut (Bonheure \& Willson, 1992), unsur ini penting dalam enzim oksidase polifenol yang sangat penting untuk fermentasi. Studi sebelumnya menunjukkan bahwa total polifenol daun meningkat akibat aplikasi pupuk daun, yang disebabkan adanya mikronutrien pada pupuk daun (Obatolu, 1999). Kandungan $\mathrm{Cu}$ di dalam pucuk teh dapat menentukan baik atau tidaknya hasil proses pengolahan teh (Haq dkk., 2014). Hal ini didukung oleh laporan Clowes \& Mitini-Nkhoma (1987) bahwa pucuk daun teh yang memiliki hara $\mathrm{Cu}$ rendah mengakibatkan pucuk daun teh tidak teroksidasi sempurna selama penggulungan, oleh karena itu pemebrian unsur hara $\mathrm{Cu}$ dapat melalui aplikasi pupuk daun.

\section{Persentase Pucuk Peko (\%)}

Hasil persentase pucuk peko tertinggi terdapat pada perlakuan pupuk tanah 50\% pada semua perlakuan pupuk mikro sebesar 49,36\% serta menunjukkan tidak adanya hasil signifikan dan interaksi antar kedua perlakuan (Tabel 3). Penerapan pupuk daun menjadi cara yang paling efektif untuk meningkatkan hasil dan kesehatan tanaman. Percobaan telah menunjukkan bahwa pemberian pupuk daun dapat meningkatkan hasil dari $12-25 \%$ bila dibandingkan dengan aplikasi pupuk tanah konvensional (Woldegebriel, 2007). Aplikasi pupuk daun paling cocok untuk pertumbuhan tunas pucuk baru karena daun muda mudah menyerap nutrisi (Bonheure \& Willson 
1992). Pengaruh unsur mikro $\mathrm{Zn}$ dan $\mathrm{Cu}$ dapat meningkatkan tingkat metabolisme karbohidrat dalam fotosintesis pada tanaman teh sehingga mampu meningkatkan pertumbuhan dan perkembangan tunas baru pada teh (Alloway, 2008). Tembaga dan Seng dianggap sebagai sumber protein yang baik (Nwajei, 2012).

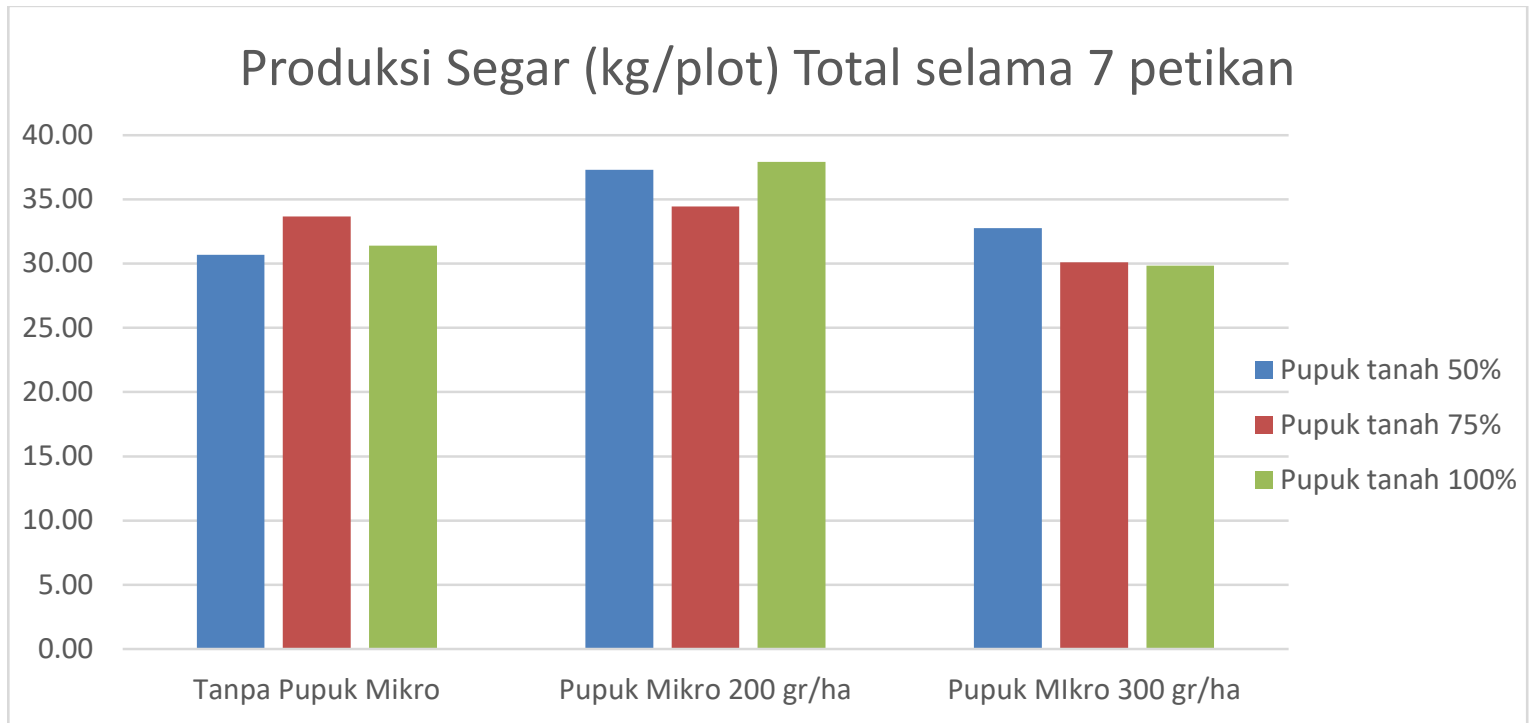

Gambar 1. Total produksi segar (kg/plot) selama 7 petikan.

Dalam pertumbuhannya, tanaman teh memerlukan ketersediaan unsur hara dan media tanah yang baik dan seimbang, terutama ketersediaan air yang cukup dan tingkat kesuburan tanah sedang sampai tinggi. Keadaan ini sangat penting bagi kelangsungan proses-proses metabolisme, respirasi dan fotosintesis. Hal ini sesuai dengan hasil pengamatan bahwa perlakuan pemberian pupuk tanah pada semua dosis pupuk mikro memberikan persentase pucuk peko tertinggi.

\section{Ratio Peko/Burung (\%)}

Dari hasil pengamatan, ratio pucuk peko dan pucuk burung diperoleh hasil tertinggi pada perlakuan pupuk tanah 50\% dosis anjuran yaitu sebesar 0,99\% (Tabel 3). Hasil rasio ini tidak menunjukkan adanya signifikansi dan interaksi antar kedua perlakuan. Nilai perbandingan (rasio) yang normal adalah 2,33, artinya dalam setiap petikan terdapat $70 \%$ jumlah pucuk peko dan $30 \%$ jumlah pucuk burung (Haq dkk., 2015). Seluruh hasil rasio pucuk peko dan burung berada dibawah normal, yaitu persentase pucuk burung lebih banyak dibandingkan pucuk peko.

Pupuk daun yang diserap tanaman dimanfaatkan untuk memulihkan kesehatan tanaman setelah terserang hama kemudian digunakan untuk produksi pucuk. Menurut Ranganathan et al. (1983) bahwa pucuk burung disebabkan karena kurang nutrisi dan dosis pupuk yang diberikan tanaman untuk menghasilkan pucuk peko. Berdasarkan penelitian (Rusmana \& Salim, 2006) bahwa berkurangnya pertumbuhan pucuk peko juga dapat disebabkan tanaman sudah masuk fase istirahat. Hal ini ditandai dengan jumlah pucuk peko yang dihasilkan selalu sedikit dibanding pucuk burung.

Peningkatan persentase pucuk burung disebabkan beberapa faktor antara lain keadaan ranting yang semakin tua dan persaingan hara antar pucuk tanaman (Dalimoenthe, 1987). Dilaporkan bahwa secara ekonomis keadaan pucuk burung (dormansi) yang tinggi dapat merugikan karena pembentukan daun muda terhenti dan produksi pucuk menurun.

Unsur Zn dapat meningkatkan kesehatan dan resistensi terhadap serangan organisme pengganggu tanaman (Sarwar, 2011). Menurut Owuor (2001) Seng memiliki efek positif pada metabolisme tanaman karena memobilisasi fotosintat terhadap tunas teh yang dipetik. Beberapa penelitian telah menunjukkan manfaat, peningkatan panen hingga mencapai 15\% dari aplikasi daun 1 sampai 2\% seng (Tolhurst, 1973). Aplikasi foliar sampai 4\% seng juga meningkatkan pengambilan nitrogen hingga 20\% (Dev et al., 1988) 
Pengaruh Suhu dan Curah Hujan terhadap Efektivitas Pemupukan dan Empoasca sp.

Kondisi lingkungan secara langsung dapat mempengaruhi jaringan tanaman dan proses fotosintesis dan secara tidak langsung mempengaruhi distribusi geografis dan dinamika populasi hama (Rezamela dkk., 2016). Curah hujan Kebun Teh Gambung selama periode pengamatan mulai bulan Januari sampai dengan Juni tahun 2016 tersaji pada Gambar 2. Dari Gambar 2 dapat dilihat bahwa, intensitas curah hujan mulai menurun pada bulan Mei dan terendah di bulan Juni 2016. Selama periode pengamatan, terdapat 1 bulan yang dikategorikan sebagai bulan kering yaitu pada bulan Juni 2016 sebesar 53,60 mm (di bawah $60 \mathrm{~mm}$ per bulan). Intensitas curah hujan tertinggi terjadi pada bulan April 2016 sebesar 301,80 mm per bulan.

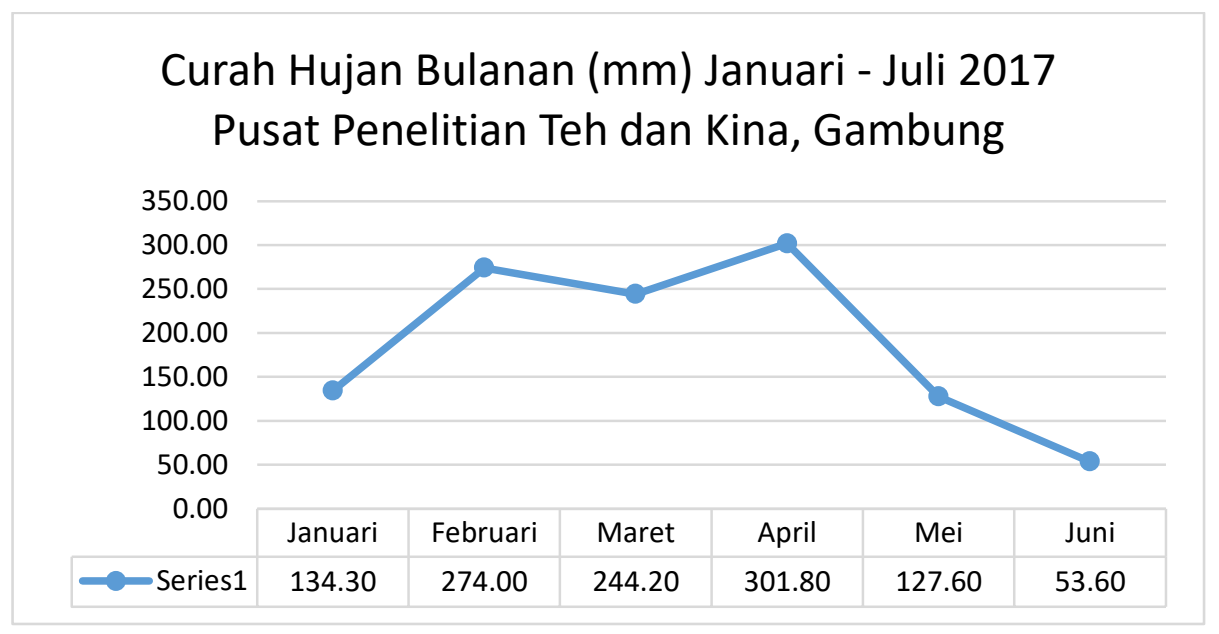

Gambar 2. Curah hujan bulanan (mm) Januari-Juni 2017.

Periode timbulnya hama sangat berhubungan dengan periode hujan tahunan. Hujan dapat memengaruhi perkembangan hama secara langsung, maupun tidak langsung. Hujan yang lebat dapat menghanyutkan serangga, sedangkan curah hujan yang rendah dapat berpengaruh tak langsung terhadap perkembangan hama karena curah hujan erat hubungannya dengan suhu maksimum, minimum serta tekanan udara (Rezamela dkk., 2016).

Pola hubungan antara curah hujan dan intensitas serangan Empoasca sp. membentuk pola polinomial. Intensitas serangan meningkat pada kondisi curah hujan rendah atau tidak ada hujan hingga intensitas curah hujan sekitar 100-140 mm, kemudian intensitas akan menurun seiring dengan peningkatan curah hujan (Rezamela et al., 2016). Hal ini yang menyebabkan tingginya intensitas serangan Empoasca sp. terus terjadi hingga pengamatan terakhir karena curah hujan yang rendah mendukung perkembangan Empoasca sp.

Selain memengaruhi perkembangan Empoasca sp., curah hujan juga memengaruhi produksi pucuk. Hubungan antara produksi pucuk teh dengan curah hujan menyebutkan bahwa tinggi rendahnya produksi teh lebih kuat berhubungan dengan curah hujan (Wisnubroto \& Rosich, 2002).
Produksi pucuk berpengaruh dengan kondisi curah hujan. Dalam hal ini air merupakan faktor pembatas pertumbuhan tunas-tunas baru. Menurut Rusmana \& Salim (2006) menyebutkan bahwa tanaman teh memerlukan curah hujan minimal $114 \mathrm{~mm}$ per bulan untuk memenuhi kebutuhan konsumsi air 1,24 mm sampai dengan 2,68 $\mathrm{mm}$ per perdu per hari. Kondisi curah hujan yang rendah selama percobaan berlangsung dapat menyebabkan kebutuhan air tanaman dan efektivitas pemupukan berkurang.

\section{SIMPULAN}

Kesimpulan yang diperoleh dari penelitian ini adalah, meskipun tidak terdapat perbedaan yang nyata dan interaksi antar faktor, namun terjadi penurunan pada rata-rata intensitas serangan dan populasi Empoasca sp. Rata-rata intensitas serangan dan populasi Empoasca sp. pada akhir pengamatan sebesar 31,64\% dan 2,55 ekor/tanaman. Sementara itu, total produksi tertinggi didapat dari aplikasi pupuk mikro Zn dan Cu dosis 200 g/ha/aplikasi pada semua dosis pupuk tanah yaitu sebesar 36,56 kg per plot, namun tidak terjadi interaksi antar faktor perlakuan. 


\section{DAFTAR PUSTAKA}

Alloway, B. J. 2008. Zinc in Soils and Crop Nutrition. Second edition. International Zinc Association (IZA)-International fertiliser Industry Association(IFA), Brussels and Paris.

Bonheure, D, and KC Willson. 1992. Mineral nutrition and fertilizers in Tea Cultivation to Consumption. (KC Willson, MN Clifford, Eds.). Chapman and Hall, London. Pp. 269330.

Clowes, MStJ, and SP Mitini-Nkhoma. 1987. Copper deficiency on young clonal tea growing close to Mulanje Mountain. Tea Research Foundation (Central Africa) Quarterly Newsletter. 88:13-15.

Dalimoenthe, SL. 1987. Dasar-dasar fisiologi pemetikan pucuk tanaman the (Camellia sinensis (L). O. Kunzte). Warta Balai Penelitian Teh dan Kina, Gambung. 13(1):29-32.

Dev Chaudhury, MN, and KL Bajaj. 1988. Effects of phosphorus on amino acid composition in tea (Camellia sinensis) shoots. Two and A Bud. 35:46-47.

Dharmadi, A. 1999. Empoasca sp. Hama Bari di Perkebunan Teh Indonesia. Prosiding Pertemuan Teknis Teh Nasional. Pusat Penelitian Teh dan Kina.

Direktorat Jenderal Bina perkebunan. 2002. Luas Areal Teh menurut Provinsi. Tersedia online pada: http://www.deptan.go.id/intoeksekutif/bun/ luas_areal_\&prodteh_perprop.htm. (diakses 30 Mei 2013)

Fauziah, F. 2013. Pengendalian terpadu Empoasca flavescens (F.) (Homoptera : Cicadellidae) di Perkebunan Teh. Warta Pusat Penelitian teh dan Kina. 24(1):55-70.

Fauziah, F, MS Haq, Karyudi, dan AI Rosyadi. 2015. Pengaruh pupuk daun dan pestisida metomil pada tanaman teh yang terserang hama: (2) Pengaruh terhadap populasi dan intensitas serangan Empoasca flavescens. Jurnal Penelitian Teh dan Kina. (18)2:145154.

Fragoyiannis, DA, RG McKinlay, and JPF D'mello. 2001. Interactions of Aphid Herbivory and Nitrogen Availability on the Total Foliar Glycoalkaloid Content of Potato Plants. Journal of Chemical Ecology. 27(9):1749-62.

Gogi, MD, JM Arif, M Asif, Zain-ul-Abdin, M H Bashir, M Ashad, M A Khan, Q Abbas, M R
Shahid, and A Anwar. 2012. Impact of nutrient management schedules on infestation of Bemisia tabaci on yield of non-BT cotton (Gossypium hirsu-tum) under unsprayed condition. Pak. Entomol. 34(1):87-92.

Haq, MS, Y Rachmiati, dan Karyudi. 2014. Pengaruh pupuk daun terhadap hasil dan komponen hasil pucuk tanaman teh (Camellia sinensis (L.) O. Kuntze var. Assamica (Mast) Kitamura). Jurnal Penelitian Teh dan Kina. 17(2):47-56.

Haq, MS, F Fauziah, dan Karyudi. 2015. Pengaruh pupuk daun nitrogen dan zink dengan pestisida Mentomil pada tanaman teh yang terserang hama Empoasca sp. (1) Pengaruh terhadap peningkatan hasil pucuk dan komponen hasil. Jurnal Penelitian Teh dan Kina. 18(1):45-54.

Hardjowigeno, S. 2007. Ilmu Tanah. Edisi baru. Akademika pressindo, Jakarta.

Kalshoven, LGE. 1981. The Pest of Crop in Indonesia. Revised and translate by PA van der Lann. PT. Ichtiar Baru-Van Heeve, Jakarta. 731p.

Nath, TN. 2013. The status of micronutrients (Mn, $\mathrm{Fe}, \mathrm{Cu}, \mathrm{Zn}$ ) in tea plantations in Dibrugarh District of Assam, India. International Research Journal of Environment Sciences. 2(6):25-30.

Njogu, RNE, DK Kariuki, DM Kamau, and FN Wachira. 2014. Effects of foliar fertilizer application on quality of tea (Camellia sinensis) grown in the Kenyan Highlands. American Journal of Plant Sciences. 5:27072715.

Nwajei, GE, P Okwagi, RI Nwajei, and G Obi-Iyeke. E. 2012. Analytical assessment of trace elements in soils, tomato leaves and fruits in the vicinity of paint industry, Nigeria. Res. J. Recent Sci. 1(4):22-26.

Obatolu, CR. 1999. Correction of magnesium deficiency in tea plants through foliar applications. Communications in Soil Science and Plant Analysis. 30:1649-1655.

Ozyazici, MA, G Ozyzici, and D Dengiz. 2011. Determination of micronutrients in tea plantations in the eastern Black Sea Region, Turkey. African Journal of Agricultural Research. 6(22):5174-5180.

Owuor, P.O. 2001. Effect of fertilizers on tea yields and quality: A review with special reference to Africa and Sri Lanka. International Journal of Tea Science. 1(1):1-11. 
PPTK (Pusat Penelitian Teh dan Kina). 2006. Petunjuk Kultur Teknis Tanaman Teh. Edisi ketiga. Pusat Penelitian Teh dan Kina, Gambung.

Rachmiati, Y, E Pranoto, dan T Trikamulya. 2013. Rekomendasi Pemupukan pada Tanaman Teh 2013 Lingkup PTPN VIII. Pusat Penelitian Teh dan Kina. Bandung. [Tidak dipublikasikan].

Ranganathan, V, K. Raman, and S. Natesan. 1983. Nutritional and physiological interactions with length of plucking rounds and banjhiness. Bulletin, United Planters Association of South India. 38:67-89.

Rezamela, E, F Fauziah, dan SL Dalimonthe. 2016. Pengaruh bulan kering terhadap intensitas serangan Empoasca sp. dan blister blight di kebun teh Gambung. Jurnal Penelitian Teh dan Kina. 19(2):169-178.

Rusmana, N, dan A. Salim. 2006. Pengaruh kombinaasi pupuk daun puder dan takaran pupuk N, P, K yang berbeda terhadap hasil pucuk tanaman teh (Camellia sinensis (L.) O. Kuntze) seedling, TRI 20125 dan GMB 4. Jurnal Penelitian Teh dan Kina. 9(1-2): 2840.

Rouhani, M, and MA Samih. 2013. Evaluation of two spring application of micronutrient on the population density of common pistachio psylla (Agonoscena pistaciae) in pistachio orchards. Journal of Plant Protection Research. 52(3):314-318.

Sarwar, M. 2011. Effects of zinc fertilizer application on theincidence of rice stem borers (Scirpophaga species) (Lepidoptera: Pyralidae) in rice (Oryza sativa L.) crop. Journal of Cereals and Oilseeds. 2(5):61-65.

Sedaghathoor, S, AM Torkashvand, D Hashemabadi, and B Kaviani. 2009. Yield and quality response of tea plant to fertilizers. African
Journal of Agricultural Research. 4(6):568570.

Sharma, VS. 2011. A Manual of Tea Cultivation. International Society of Tea Science. Pradesh. Pp. 64-66.

Sucherman, O, dan W Widayat. 2001. Konsep organisasi dan cara monitoring serangan Empoasca sp. dan Helopelthis antonii pada budidaya teh organik. Prosiding Seminar Budidaya Teh Organik. Pusat Penelitian The dan Kina.

Sucherman, O, dan O Sukandi. 2008. Pengaruh jumlah perangkap lem serangga terhadap populasi dan intensitas serangan Empoasca pada tanaman teh. Jurnal Penelitian Teh dan Kina. 11(3):80-91.

Tolhurst, JAH. 1973. Zinc deficiency in tea. Tea Research Institute of East Africa Pamphlet No 21/73.

Watanabe, T, M Urayama, T Shinano, R Okada, and M Osaki. 2015. Application of ionomics to plant and soil in fields under long-term fertilizer trials. Springerplus. 4:781.

Widayat, W. 2000. Hama penting pada tanaman teh dan cara pengendaliannya. Pusat Penelitian Teh dan Kina. Proyek Penelitian Pengendalian Hama Terpadu.

Widayat, W. 2008. Pengaruh penggunaan mulsa terhadap fluktuasi populasi dan intensitas serangan Empoasca sp. Jurnal Penelitian Teh dan Kina. 11(3):45-57.

Wisnubroto, S, dan A Rosich. 2002. Prakiraan hasil pucuk teh atas dasar jumlah hujan bulanan di Kebun Pagilaran. Jurnal Ilmu Tanah dan Lingkungan. 3(1):42-44.

Woldegebriel, D. 2007. Levels of essential and nonessential metals in commercially available ethiopian black teas. [Thesis]. Addis Ababa University, Ethiopia. 